\title{
Serum and seminal plasma insulin-like growth factor-1 in male infertility
}

\author{
Hyo Serk Lee', Yong-Seog Park', Joong Shik Lee', Ju Tae Seo' \\ 'Department of Urology, ${ }^{2}$ Laboratory of Reproductive Biology and Infertility, Cheil General Hospital and Women's Healthcare Center, Dankook \\ University College of Medicine, Seoul, Korea
}

\begin{abstract}
Objective: Growth hormone and its mediator, insulin-like growth factor-1 (IGF-1), have been suggested to exert gonadotropic actions in both humans and animals. The present study was conducted to assess the relationship between serum IGF-1 concentration, seminal plasma concentration, and sperm parameter abnormalities.

Methods: A total of 79 men were enrolled in this study from December 2011 to July 2012 and were prospectively analyzed. Patient parameters analyzed included age, body mass index, smoking status, urological history, and fertility history. Patients were divided into four groups based on their semen parameters: normal $(A, n=31)$, abnormal sperm motility $(B, n=12)$, abnormal sperm morphology $(C, n=20)$, and two or more abnormal parameters $(D, n=16)$. Patient seminal plasma and serum IGF-1 concentrations were determined.

Results: Patient baseline characteristics were not significantly different between any of the groups. The serum IGF-1 levels in groups B, C, and D were significantly lower than the levels in group A; however, the seminal plasma IGF-1 levels were not significantly different between any of the groups.

Conclusion: Men with abnormal sperm parameters had significantly lower levels of serum IGF-1 compared with men with normal sperm parameters. Seminal plasma IGF-1 levels, however, did not differ significantly between the groups investigated here. Further investigations will be required to determine the exact mechanisms by which growth hormone and IGF-1 affect sperm quality.
\end{abstract}

Keywords: Infertility; Insulin-like growth factor-1; Male; Semen; Serum

\section{Introduction}

Infertility is defined as the inability to conceive after 1 year of unprotected intercourse. Approximately $15 \%$ of all human couples are recognized as infertile, and about $50 \%$ of these cases are associated with male fertility factors. Although overall human fertility does not appear to have declined in recent years, some evidence indicates

Received: Jan 24, 2016 · Revised: Mar 24, 2016 • Accepted: Apr 16, 2016 Corresponding author: Ju Tae Seo

Department of Urology, Cheil General Hospital and Women's Healthcare Center, Dankook University College of Medicine, 17 Seoae-ro 1-gil, Jung-gu, Seoul 04619, Korea

Tel: +82-2-2000-7585 Fax:+82-2-2000-7787 E-mail:jtandro@cgh.co.kr

This study received financial support from LG Life Sciences (IIT-2011-04).

This is an Open Access article distributed under the terms of the Creative Commons Attribution Non-Commercial License (http://creativecommons.org/licenses/by-nc/4.0/) which permits unrestricted non-commercial use, distribution, and reproduction in any medium, provided the original work is properly cited. that sperm quality has declined [1]. To date, multiple factors have been implicated in reduced sperm count and motility. These factors include genito-urinary infections, environmental exposure to hazardous chemicals that are detrimental to spermatogenesis, anatomic and physical obstructions, hormonal imbalances, immunologic deficiencies, and abnormal morphology.

Spermatogenesis is a complex developmental process that requires pituitary gonadotrophins and testosterone, which indirectly regulate spermatogenic cells and testicular functions in autocrine, paracrine, and juxtacrine manners. One of the molecules thought to be involved in the development of germ cells is insulin-like growth factor-1 (IGF-1), a 7.6-kDa polypeptide of 70 amino acids that mediates the cell-proliferating actions of growth hormone (GH). IGF-1 is found in plasma and tissue fluid, and influences steroidogenesis, metabolism, cell proliferation, and differentiation [2,3]. IGF-1 also affects various reproductive processes and plays an essential role in the onset, 
progress, and regulation of spermatogenesis [4]. IGFs are produced mainly in the liver, and are released in response to pulsatile secretions of GH from the anterior pituitary [5]. In the male reproductive tract, IGF-1 has been found in the testis [6], where it is secreted by Leydig cells and Sertoli cells [7-9]. Receptors for IGF-1 have been identified on Sertoli cells [10], Leydig cells [8], secondary spermatocytes, spermatids [9,11], and spermatozoa [12,13]. Furthermore, IGF1 is thought to be involved in spermatogenesis [14-17] and steroidogenesis [18]. IGF-1 also appears in the peripheral circulation, where it exists primarily in a heavy tertiary complex with IGF-binding protein-3 and acid-labile subunit $[19,20]$.

However, only a few studies have investigated the semen and serum levels of IGF-1. One study investigated these levels in normal fertile and vasectomized men, whereas the other identified variable levels of IGF-1 in infertile men [3,21]. To obtain a better understanding of the role of IGF-I in fertility, the present study aimed to determine the relationship between serum IGF-1 concentration, seminal plasma IGF-1 concentration, and sperm parameter abnormalities.

\section{Methods}

\section{Study design}

Data from 79 men who were enrolled in this study from December 2011 to July 2012 were prospectively analyzed. Written informed consent was obtained from each subject before entering the study. This study was performed in accordance with the principles of the Declaration of Helsinki and with the approval of the Cheil General Hospital Institutional Review Board (CGH-IRB-2011-76). All patients received medical care from the same doctor at a single hospital. Patient parameters analyzed included age, height, weight, body mass index (BMI), smoking status, urological history, and fertility history. Exclusion criteria included diabetes mellitus; liver, renal, or thyroid disease; past or current cancer; a history of genito-urinary tract infections; azoospermia; and any surgical history or medications that could have affected semen parameters. According to the fifth edition of the World Health Organization guidelines, the patients were divided into the following four groups based on their semen parameters: normal $(A, n=31)$, abnormal sperm motility $(B, n=12)$, abnormal sperm morphology $(C, n=20)$, and two or more abnormal parameters $(D, n=16)$. Seminal plasma and serum concentrations of IGF-1 were determined for each subject.

\section{Hormonal assay}

Serum and seminal IGF-1 levels were assessed via radioimmunoassay. Briefly, samples and standards were incubated in tubes that had previously been coated with the first monoclonal antibody in the presence of a second monoclonal antibody, which was labeled with iodine-125. After incubation, the tube contents were removed and the amounts of bound radioactive iodine-125 were measured. Unknown values were determined by interpolation from a standard curve; standard curve measurements were taken at the same time as those of the samples. The amount of bound radioactivity was directly proportional to the IGF-1 concentration in each sample. All reagents in the kit used were stable until the expiry date, per the kit label, if stored at $2^{\circ} \mathrm{C}$ to $8^{\circ} \mathrm{C}$. Storage conditions for reagents after reconstitution or dilution are included in the detailed description of the assay procedures.

\section{Statistical analysis}

The PRISM software package ver. 4.10 (GraphPad, La Jolla, CA, USA) was used for statistical analysis. Significance was set at $p<0.05$ with a confidence interval of $95 \%$. Spearman's rank correlation analysis was used to assess the relationships between serum IGF-1 levels, semen IGF-1 levels, and other semen variables. Quantitative parametric data are represented as means and standard deviations. Student's ttest was used to compare means between groups, whereas one-way analysis of variance was used to compare more than two groups. Intra-group differences were assessed using a post hoc test and by calculating the least significant difference.

\section{Results}

The principal characteristics of patients with normal and abnormal semen parameters are listed in Table 1. Body weight is heavier in

Table 1. Baseline characteristics of each group

\begin{tabular}{|c|c|c|c|c|c|}
\hline Characteristics & Group A $(n=31)$ & Group B $(n=12)$ & Group C $(n=20)$ & Group D $(n=16)$ & $p$-value \\
\hline Age (yr) & $35.2 \pm 3.2$ & $34.7 \pm 5.3$ & $35.5 \pm 3.3$ & $35.4 \pm 3.6$ & 0.949 \\
\hline Body weight $(\mathrm{kg})$ & $75.0 \pm 9.8$ & $70.6 \pm 7.0$ & $80.5 \pm 8.0$ & $75.8 \pm 10.5$ & 0.038 \\
\hline Height $(\mathrm{cm})$ & $175.1 \pm 5.9$ & $174.2 \pm 6.5$ & $175.6 \pm 6.0$ & $174.7 \pm 5.6$ & 0.922 \\
\hline Body mass index $\left(\mathrm{kg} / \mathrm{m}^{2}\right)$ & $24.47 \pm 3.2$ & $23.18 \pm 1.8$ & $26.05 \pm 2.4$ & $24.82 \pm 3.0$ & 0.054 \\
\hline
\end{tabular}

Values are presented as mean \pm standard deviation.

Group A, normal semen parameters; Group B, abnormal sperm motility; Group C, abnormal sperm morphology; Group D, more than two abnormal semen parameters. 
Table 2. Semen parameters, serum IGF-1 level, and seminal plasma IGF-1 level of each group

\begin{tabular}{lcccc}
\hline Variable & Group $A(n=31)$ & Group B $(n=12)$ & Group C $(n=20)$ & Group D $(n=16)$ \\
\hline Semen parameter & & & & $3.2 \pm 1.2$ \\
Volume $(\mathrm{mL})$ & $2.5 \pm 1.0$ & $3.7 \pm 1.8$ & $79.8 \pm 50.6$ & $3.7 \pm 1.6$ \\
Concentration $\left(10^{6} / \mathrm{mL}\right)$ & $153.4 \pm 67.5$ & $67.6 \pm 42.0$ & $59.7 \pm 12.0$ & $34.4 \pm 32.9$ \\
Motility (\%) & $68.8 \pm 14.5$ & $27.9 \pm 5.7$ & $0.5 \pm 0.8$ & $27.1 \pm 12.8$ \\
Morphology (\%) & $14.0 \pm 9.3$ & $8.3 \pm 4.2$ & $61.3 \pm 13.5$ & $0.5 \pm 1.0$ \\
Viability (\%) & $77.1 \pm 13.2$ & $47.36 \pm 18.2$ & & $42.6 \pm 31.2$ \\
IGF-I (ng/mL) & & & $144.4 \pm 25.8^{\text {b) }}$ & $130.6 \pm 28.2^{\text {c) }}$ \\
Serum & $175.4 \pm 42.7$ & $137.3 \pm 7.3^{\text {a) }}$ & $18.7 \pm 4.0$ & $15.9 \pm 5.9$ \\
Seminal plasma & $15.4 \pm 8.3$ & $15.6 \pm 5.8$ & & \\
\hline
\end{tabular}

Values are presented as mean \pm standard deviation.

Group A, normal semen parameters; Group B, abnormal sperm motility; Group C, abnormal sperm morphology; Group D, more than two abnormal semen parameters; IGF-1, insulin-like growth factor-1.

${ }^{\text {a) }} p<0.001 ;{ }^{\text {b) }} p<0.05$; $^{\text {c) }} p<0.01$; multiple comparison test.

Table 3. Semen parameters, serum IGF-1 levels, and seminal plasma IGF-1 levels of the normal and abnormal semen parameter groups

\begin{tabular}{lcc}
\hline Parameter & Group A $(\mathrm{n}=31)$ & Groups B+C+D $(\mathrm{n}=48)$ \\
\hline Semen parameter & & \\
Volume $(\mathrm{mL})$ & $2.5 \pm 1.0$ & $3.5 \pm 1.5$ \\
Concentration $\left(10^{6} / \mathrm{mL}\right)$ & $153.4 \pm 67.5$ & $61.1 \pm 46.8$ \\
Motility $(\%)$ & $68.8 \pm 14.5$ & $40.7 \pm 19.4$ \\
Morphology (\%) & $14.0 \pm 9.3$ & $2.4 \pm 4.0$ \\
Viability (\%) & $77.1 \pm 13.2$ & $51.4 \pm 23.3$ \\
IGF-I (ng/mL) & & \\
Serum & $175.4 \pm 42.7$ & $137.6 \pm 27.1^{\text {a) }}$ \\
Seminal plasma & $15.4 \pm 8.3$ & $17.0 \pm 5.2$
\end{tabular}

Values are presented as mean \pm standard deviation.

IGF-1, insulin-like growth factor-1; Group A, normal semen parameters; Group B, abnormal sperm motility; Group C, abnormal sperm morphology; Group D, more than two abnormal semen parameters.

a) $p<0.001$, two-sided $t$-test.

group C; however, BMI did not significantly differ between groups. The serum IGF-1 levels of the abnormal sperm motility group (B), the abnormal sperm morphology group $(C)$, and the group with two or more abnormal parameters (D) were significantly lower than those of the normal group (A). However, no significant between-group differences were observed regarding the IGF-1 levels of seminal plasma (Table 2). Next, the IGF-1 levels of the normal (A) and abnormal (B, $C$, and $D)$ groups were compared. This analysis revealed that the abnormal group showed significantly lower serum levels of IGF-1 compared with the normal group. However, the seminal plasma IGF-1 levels were not significantly different between the normal $(A)$ and abnormal (B, $C$, and D) groups (Table 3). In a Spearman's correlation test, the serum IGF-1 level is correlated with semen volume, sperm motility, and sperm viability (Table 4).
Table 4. Correlation analysis between serum IGF-1 and clinical parameters

\begin{tabular}{lcccc}
\hline Parameter & No. of XY pairs & Spearman's $r$ & $\begin{array}{c}p \text {-value } \\
\text { (two-tailed) }\end{array}$ & $\begin{array}{c}p \text {-value } \\
\text { summary }\end{array}$ \\
\hline Age & 98 & -0.035 & 0.731 & $\mathrm{NS}$ \\
Weight & 98 & 0.036 & 0.720 & $\mathrm{NS}$ \\
Height & 98 & -0.061 & 0.549 & $\mathrm{NS}$ \\
BMl & 98 & 0.105 & 0.300 & $\mathrm{NS}$ \\
TMSC & 98 & 0.140 & 0.169 & $\mathrm{NS}$ \\
Semen parameter & & & & \\
$\quad$ Volume & 98 & -0.251 & 0.012 & $<0.05$ \\
Concentration & 98 & 0.192 & 0.058 & $\mathrm{NS}$ \\
$\quad$ Motility & 98 & 0.202 & 0.045 & $<0.05$ \\
$\quad$ Viability & 98 & 0.254 & 0.011 & $<0.05$ \\
\hline
\end{tabular}

IGF-1, insulin-like growth factor-1; BMI, body mass index; NS, not significant; TMSC, total motile sperm count.

\section{Discussion}

Studies of children and adolescents have indicated an age-related increase in serum IGF-1 levels during the prepubertal and early pubertal stages, followed by a decrease in late puberty [22-25]. Other studies have also shown that serum IGF-1 levels change with age; for instance, Korean men aged 30 to 49 years old were shown to have serum IGF-1 levels that exceeded $180 \mathrm{ng} / \mathrm{mL}$ [24]. The mean subject age in our study was 35.2 years, with a range of 30 to 49 years.

Overall, the serum IGF-1 levels measured in our study were relatively low. This finding might be due to the size of our target group, which could have affected the results due to bias in the measuring tools. We found that the serum IGF-1 levels of the abnormal motility group (B, mean $=137.3 \pm 7.3 \mathrm{ng} / \mathrm{mL}$ ), the abnormal morphology group $(C$, mean $=144.4 \pm 25.8 \mathrm{ng} / \mathrm{mL}$ ), and the group with two or more abnormal parameters $(D$, mean $=130.6 \pm 28.2 \mathrm{ng} / \mathrm{mL})$ were significantly low- 
er than the levels in the normal group $(A$, mean $=175.4 \pm 42.7 \mathrm{ng} / \mathrm{mL})$.

Only a few studies have assessed the relationship between serum/ seminal IGF-1 and semen quality. In these studies, males with infertility due to oligospermia had the lowest mean and median levels of seminal IGF-1. These levels were significantly different from the levels in the fertile and immuno-infertile groups, as well as from the other male-factor infertile subgroups. These findings suggest that lower seminal IGF-1 levels are associated with oligospermia [2]. However, we did not observe a significant relationship between semen parameters and seminal IGF-1 in this study, although we did identify a significant relationship between semen parameters and the serum level of IGF-1.

Both morphologically normal sperm and the seminal levels of IGF1 have been reported to be decreased in males who smoke. Specifically, infertile smokers had the lowest seminal IGF-1 values, followed by infertile nonsmokers, fertile smokers, and control subjects [26]. These findings indicate that reduced IGF-1 is associated with both smoking and infertility.

Seminal IGF-1 has also been shown to have a significant positive correlation with the number of motile and rapid linear progressive spermatozoa [24]. IGF-1 production stimulates spermatozoa maturation in a paracrine/autocrine manner, thereby increasing sperm motility [3]. Thus, IGF-1 might function as a differentiation marker in male germ cells. Colombo and Naz [2] also showed that the seminal IGF-1 level exhibited a significant linear correlation with the total sperm count. Although sperm count was not directly investigated in the present study, it is taken indirectly into account for group D. Consistent with other studies, we observed decreased seminal IGF-1 levels in this group; however, this decrease was not significant. A limitation of this study is that subjects in the normal semen parameter group are also infertile male patients; thus, improved fertile male subjects will be needed for comparison of IGF-1 levels.

We found that the groups with abnormal sperm parameters exhibited significantly lower levels of serum IGF-1 compared with the normal group. Seminal plasma IGF-1 levels, however, did not differ significantly between the groups investigated here. Further investigations will be required to determine the exact mechanisms by which GH and IGF-1 affect fertility.

\section{Conflict of interest}

No potential conflict of interest relevant to this article was reported.

\section{References}

1. Auger J, Kunstmann JM, Czyglik F, Jouannet P. Decline in semen quality among fertile men in Paris during the past 20 years. $\mathrm{N}$
Engl J Med 1995;332:281-5.

2. Colombo JB, Naz RK. Modulation of insulin-like growth factor-1 in the seminal plasma of infertile men. J Androl 1999;20:118-25.

3. Glander HJ, Kratzsch J, Weisbrich C, Birkenmeier G. Insulin-like growth factor-I and alpha 2-macroglobulin in seminal plasma correlate with semen quality. Hum Reprod 1996;11:2454-60.

4. Dyck MK, Ouellet M, Gagn M, Petitclerc D, Sirard MA, Pothier F. Testes-specific transgene expression in insulin-like growth factor-I transgenic mice. Mol Reprod Dev 1999;54:32-42.

5. Bartke A. Effects of growth hormone on male reproductive functions. J Androl 2000;21:181-8.

6. Hess MF, Roser JF. The effects of age, season and fertility status on plasma and intratesticular insulin-like growth factor I concentration in stallions. Theriogenology 2001;56:723-33.

7. Handelsman DJ, Spaliviero JA, Scott CD, Baxter RC. Identification of insulin-like growth factor-I and its receptors in the rat testis. Acta Endocrinol (Copenh) 1985;109:543-9.

8. Smith EP, Svoboda ME, Van Wyk JJ, Kierszenbaum AL, Tres LL. Partial characterization of a somatomedin-like peptide from the medium of cultured rat Sertoli cells. Endocrinology 1987;120: 186-93.

9. Vannelli BG, Barni T, Orlando C, Natali A, Serio M, Balboni GC. Insulin-like growth factor-I (IGF-I) and IGF-I receptor in human testis: an immunohistochemical study. Fertil Steril 1988;49:666-9.

10. Borland K, Mita M, Oppenheimer CL, Blinderman LA, Massague J, Hall PF, et al. The actions of insulin-like growth factors I and II on cultured Sertoli cells. Endocrinology 1984;114:240-6.

11. Tres LL, Smith EP, Van Wyk JJ, Kierszenbaum AL. Immunoreactive sites and accumulation of somatomedin-C in rat Sertoli-spermatogenic cell co-cultures. Exp Cell Res 1986;162:33-50.

12. Henricks DM, Kouba AJ, Lackey BR, Boone WR, Gray SL. Identification of insulin-like growth factor I in bovine seminal plasma and its receptor on spermatozoa: influence on sperm motility. Biol Reprod 1998;59:330-7.

13. Naz RK, Padman P. Identification of insulin-like growth factor (IGF)-1 receptor in human sperm cell. Arch Androl 1999;43:153-9.

14. Skinner MK. Cell-cell interactions in the testis. Endocr Rev 1991; 12:45-77.

15. Soder O, Bang P, Wahab A, Parvinen M. Insulin-like growth factors selectively stimulate spermatogonial, but not meiotic, deoxyribonucleic acid synthesis during rat spermatogenesis. Endocrinology 1992;131:2344-50.

16. Spiteri-Grech J, Nieschlag E. Paracrine factors relevant to the regulation of spermatogenesis: a review. J Reprod Fertil 1993; 98:1-14.

17. Tsuruta JK, O'Brien DA. Sertoli cell-spermatogenic cell interaction: the insulin-like growth factor-II/cation-independent man- 
nose 6-phosphate receptor mediates changes in spermatogenic cell gene expression in mice. Biol Reprod 1995;53:1454-64.

18. Saez JM. Leydig cells: endocrine, paracrine, and autocrine regulation. Endocr Rev 1994;15:574-626.

19. Baxter RC, Martin JL, Beniac VA. High molecular weight insulinlike growth factor binding protein complex: purification and properties of the acid-labile subunit from human serum. J Biol Chem 1989;264:11843-8.

20. Rechler MM. Insulin-like growth factor binding proteins. Vitam Horm 1993;47:1-114.

21. Ovesen P, Flyvbjerg A, Orskov H. Insulin-like growth factor I (IGF-I) and IGF binding proteins in seminal plasma before and after vasectomy in normal men. Fertil Steril 1995;63:913-8.

22. Andrade Olivie MA, Garcia-Mayor RV, Gonzalez Leston D, Rodriguez Sousa T, Segura Dominguez A, Alvarez-Novoa R, et al. Serum insulin-like growth factor (IGF) binding protein-3 and IGF-I levels during childhood and adolescence: a cross-sectional study. Pediatr Res 1995;38:149-55.

23. Juul A, Holm K, Kastrup KW, Pedersen SA, Michaelsen KF, Scheike T, et al. Free insulin-like growth factor I serum levels in 1430 healthy children and adults, and its diagnostic value in patients suspected of growth hormone deficiency. J Clin Endocrinol Metab 1997;82:2497-502.

24. Lee KO, Ng SC, Lee PS, Bongso AT, Taylor EA, Lin TK, et al. Effect of growth hormone therapy in men with severe idiopathic oligozoospermia. Eur J Endocrinol 1995;132:159-62.

25. Lofqvist C, Andersson E, Gelander L, Rosberg S, Blum WF, Albertsson Wikland K. Reference values for IGF-I throughout childhood and adolescence: a model that accounts simultaneously for the effect of gender, age, and puberty. J Clin Endocrinol Metab 2001;86:5870-6.

26. Hassan A, Abo-Azma SM, Fayed SM, Mostafa T. Seminal plasma cotinine and insulin-like growth factor-I in idiopathic oligoasthenoteratozoospermic smokers. BJU Int 2009;103:108-11. 